\title{
Historical perspectives of The American Association for Thoracic Surgery: Brian B. Blades (1906-1977)
}

\author{
John Conte, MD
}

\begin{abstract}
Whenever debates arise of the historical impact of important sports figures, it is often difficult to compare individuals from different eras. The older individual's accomplishments tend to become obscured or diminished with time, particularly when the discussants do not have firsthand knowledge of the individual from a prior generation. For example, who was the greatest home run hitter-Babe Ruth or Hank Aaron? Similar questions surface when discussing the impact of individual surgeons on the development of cardiothoracic surgery as a surgical specialty. I would argue that Dr Brian B. Blades was one of the most important individuals in the development of our field; however, many surgeons, particularly those trained in the past 2 decades, are not familiar with the breadth of his contributions and do not accord him the historical importance he is rightly due. My goal is to describe the man and his career so that his influence on the development of the field of cardiothoracic surgery can be put into perspective by those who are not familiar with his contributions.
\end{abstract}

Brian Brewer Blades, the 37th president of The American Association for Thoracic Surgery (Figure 1), was born in the rural farming community of Scottsville, Kansas, on the 4th of July, 1906. Scottsville is a small town in Mitchell County, located in the plains of north central Kansas. Scottsville measures less than 2 square miles and has a population of fewer than 25 citizens. Blades was an only child and spent his early years in Scottsville, until his family moved to the much larger city of Salina in the heart of Kansas. Blades received a public school education in Salina, where he excelled both academically and athletically. He was an all-state selection in basketball and football and graduated at the top of his class. Blades was a popular youth and carried the nickname "Blackie" (for his big, bushy eyebrows) throughout his life. He earned an athletic scholarship to Kansas Wesleyan University and was a 2-way starter (both offense and defense) on the football team. Unfortunately, he suffered a severe knee injury that ended his

\footnotetext{
From Division of Cardiac Surgery, Department of Surgery, Johns Hopkins Medical Institutions, Baltimore, Md.

Received for publication April 12, 2011; accepted for publication April 25, 2011; available ahead of print Aug 8, 2011.

Address for reprints: John Conte, MD, Johns Hopkins Medical Institutions, Department of Surgery, Division of Cardiac Surgery, $600 \mathrm{~N}$ Wolfe St, Blalock 618, Baltimore, MD 21287 (E-mail: jconte@csurg.jhmi.jhu.edu).

J Thorac Cardiovasc Surg 2012;143:776-9

0022-5223/\$36.00

Copyright (C) 2012 by The American Association for Thoracic Surgery doi:10.1016/j.jtcvs.2011.04.024
}

athletic career and changed the course of his life. Unable to play sports, Blades transferred to the University of Kansas where he received a bachelors' degree with honors.

Blades was the only child of a country doctor and chose to follow in his father's footsteps. He developed an early interest in the medical field and, over the years, regaled his children with many stories of traveling with his father, Dr Samuel T. Blades, to make house calls, initially in a horse and buggy. ${ }^{1}$ After graduating from Kansas he matriculated at Washington University School of Medicine is St. Louis, from which he graduated cum laude and Alpha Omega Alpha in 1932.

\section{TRAINING AND EARLY CAREER}

Dr Blades did a rotating internship at the Henry Ford Hospital in 1932, after which he completed a surgical residency at Bellevue Hospital in New York City in 1936. During his residency, Dr Blades developed "Ludwig angina," an infectious disease causing inflammation of the soft tissues of the neck. He had an acute respiratory arrest and required an emergency tracheostomy in an elevator! Remarkably, he survived but was no doubt impacted by this event, which clearly threatened his life. Importantly, this illness changed the tenor of his voice and limited the vocal range of this amateur singer, according to his daughter Judy. On completion of his general surgery training, Blades received the prestigious Rockefeller Scholarship and returned to St Louis for further training in thoracic surgery under Dr Evarts Graham. At this point in the United States, there was limited training available in thoracic surgery. Dr Blades was one of the first thoracic trainees at Washington University, which was the second training program in the United States (Dr John Alexander initiated the first thoracic training program at the University of Michigan).

On completing his thoracic surgery training, Blades joined the faculty at Washington University and was charged with organizing the thoracic surgery residency program. When World War II began, Dr Blades took a leave of absence from Washington University and enrolled in the army. He initially served in the Army Medical Corps in North African and then was appointed chief of thoracic surgery at Walter Reed Medical Center in Washington, DC, from 1942 to 1946. He served as a consultant in surgery to the army's surgeon general for many years and was awarded the Legion of Merit for his wartime service. Along with Dr David Duggan at Walter Reed, Dr Blades developed a series of over 350 pulmonary resections from 1942 to 1946 without a death, quite an accomplishment for that era. 


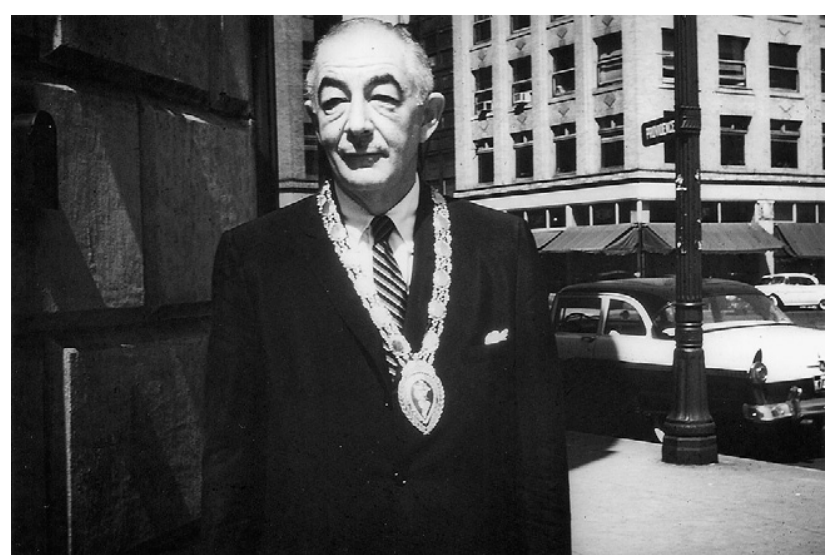

FIGURE 1. Dr Brian B. Blades wearing the Presidential Medallion.

\section{GEORGE WASHINGTON UNIVERSITY}

After the war, Dr Blades became the first full-time faculty member at George Washington University (GW) as professor and chairman of the Department of Surgery. He was charged not only with running the department but also with the reorganization from a volunteer to full-time faculty at the university. During this time, Dr Blades became an important national and international medical figure. After formally leaving the military in 1946, he continued to serve the US government as a consultant to the Veterans Administration, the National Institutes of Health, Walter Reed Army Medical Center, St Elizabeth's Hospital, the US Air Force Surgeon General, and the Department of Defense, assisting in the development of the modern military hospital system. Dr Blades was the Lewis Saltz Professor and Chairman of the Department of Surgery until 1970, when he electively stepped down.

\section{PERSONAL LIFE}

Dr Blades married his high school sweetheart and fellow Kansan, Virginia Lawton, on January 1, 1930. Virginia, too, was an only child, and together they raised 3 children, Brian Lawton Blades (deceased), Judy Blades Hunt of Lewes, Delaware, and Beverly Blades Cagnon of Agoura Hills, California. His son was nicknamed "Hap" because of his generally happy outlook on life. Ironically, Hap died of the disease that his father received much acclaim for treating, cancer of the lung. Both daughters and 4 grandchildren survive. Blades' daughter-in-law, Betty, Hap's widow, resides in the Washington, DC, area.

Dr Blades was an outdoorsman and enjoyed an active lifestyle. As an adopted Marylander, he developed a love for Maryland's Eastern Shore and spent many hours surf fishing with family and friends in Ocean City. None of his children followed their father into medicine, but they did share his love of the outdoors and tennis, in particular. Blades loved dogs and had a pet schnauzer named Heinrich that was always at his side. Blades also had a most unusual hobby for a surgeon-his daughter-in-law reported that he knitted to relax and to keep his fingers nimble for surgery.

\section{CLINICAL CAREER}

Dr Blades placed a premium on clinical excellence and was proud to be considered a "get you well surgeon," the type of individual who used surgical skill, clinical judgment, and simple common sense to get patients better. ${ }^{2}$ Figure 2 depicts Dr Blades on the cover of Modern Medicine magazine in 1966. As expected, by virtue of the era in which he worked, Blades was primarily a general thoracic surgeon. A little known fact, however, is that while performing thoracic surgery at GW, he and his colleague, Dr Howard Pierpont, performed finger fracture mitral commissurotomy surgery at the Mount Alto Veterans Administration hospital, making him one of the first cardiac surgeons in the nation's capital!

Dr Blades' position in Washington, DC, provided him the opportunity to care for many luminaries and government figures, none more prominent than the president of the United States. On June 9, 1956, Blades assisted in an

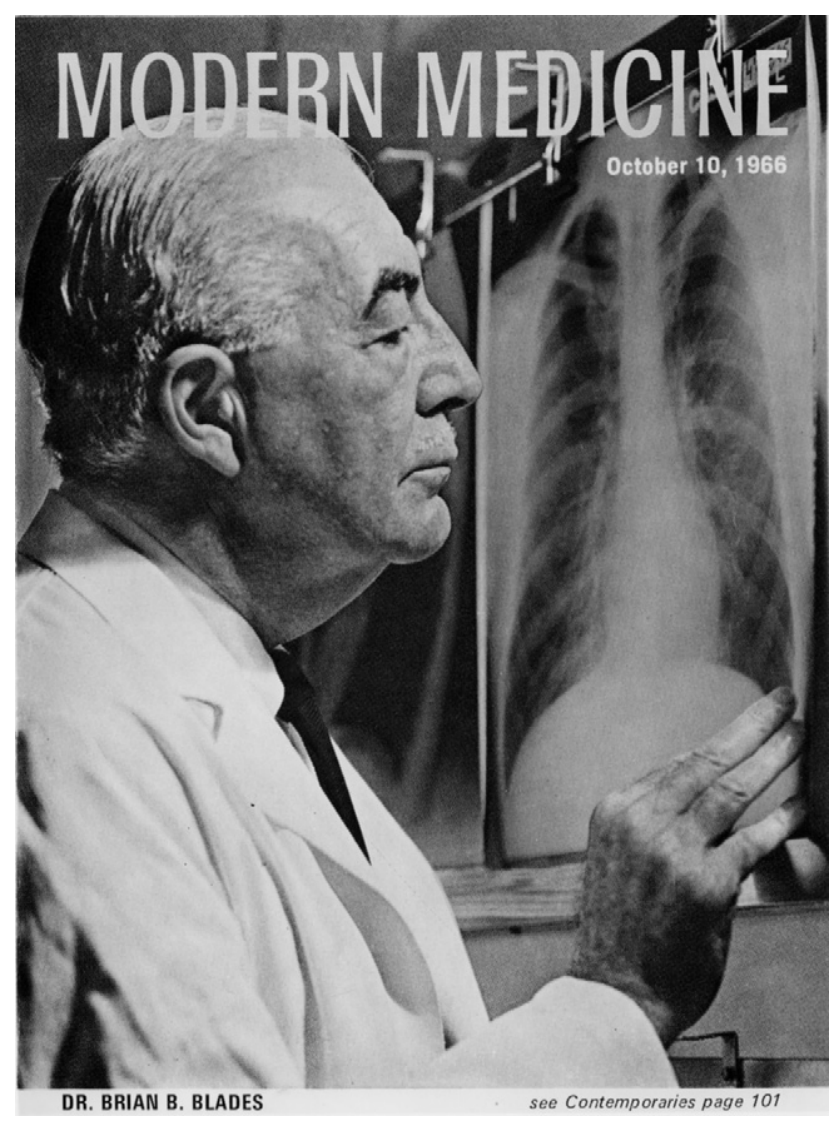

FIGURE 2. Dr Blades on the cover of Modern Medicine magazine in 1966. (Photograph courtesy of the Archives of George Washington University, Washington, DC.) 
operation on President Dwight D. Eisenhower, who required a laparotomy and bowel resection owing to an obstruction caused by complications from Crohn disease. Even though Blades was a thoracic surgeon, his stature was so great in the national medical community that he was asked to participate in the operation at Walter Reed Army Medical Center. Eisenhower had a complete recovery. As it turned out, Dr Blades and President Eisenhower, who shared Kansas roots and a love of fishing, became lifelong friends.

\section{ACADEMIC CAREER AND SURGICAL EDUCATOR}

Dr Blades' curriculum vitae contained approximately 150 articles dealing with a broad range of topics in surgery. His textbook, Surgical Diseases of the Chest, survived through 4 editions and was one of the most widely used textbooks of its era. One of Blades' most significant contributions as a surgical investigator was an article that he published in 1940 with Dr Edward Kent describing individual ligation of hilar vessels to permit anatomic lobar lung resections. This was a significant advance over the mass ligation technique and dramatically improved results for pulmonary resection across the globe.

Judy Blades recently reminisced that her father believed that his most important job as a surgeon, and the one he enjoyed the most, was as an educator. Dr Blades taught medical students, nurses, and general and thoracic surgical residents during his long tenure at GW. He lectured and taught in the clinic, operating room, and during weekly "professor rounds." Dr Blades believed that surgeons should be physicians and not just technicians and that their knowledge base should be broad, including an appreciation of medical history. A story recounted at the Statesman in Medicine Award in 1969 by master of ceremonies Eddie Albert illustrated this belief. In the operating room, Dr Blades once asked a young trainee a question about Harvey Cushing, to which the young fellow replied, "He was before my time." Without hesitation, Blades responded, "So was Jesus, but you ought to know something about him." 3

One measure of an educator's impact is the contributions of his trainees. The thoracic surgery training program at GW was the only program in Washington, DC, and many of Dr Blades' trainees had a very significant impact on the development of our specialty through their academic and clinical accomplishments. Among the most notable were Drs Donald Effler, Blades' first thoracic resident, and Floyd Loop, who made seminal contributions to the development of cardiac surgery at the Cleveland Clinic and were eventual president's of the Society of Thoracic Surgery and The American Association for Thoracic Surgery, respectively. Dr Blades was a founding member of the American Board of Thoracic Surgery in 1948, and his pupil, Dr Paul Adkins, who succeeded him as the chief of surgery at GW, became president of the American Board of Tho- racic Surgery and Society of Thoracic Surgeons, as did Dr George McGovern who, like Adkins, left Johns Hopkins after completing general surgery to train in thoracic surgery at GW under Blades. Dr Blades was the third editor of the Journal of Thoracic and Cardiovascular Surgery, serving from 1962 until shortly before his death in 1977.

\section{HONORS}

Dr Blades delivered his presidential address to The American Association for Thoracic Surgery in Boston, Massachusetts, in 1958. In his address, he summarized the first single-stage pneumonectomy performed by Dr Evarts Graham in 1933 and the interesting circumstances surrounding this watershed event. His address served as a memorial to Dr Graham the year after his death and included the interesting fact that Graham's first pneumonectomy patient, Dr James Gilmore, an obstetrician/gynecologist, not only out-survived Graham but attended his funeral.

In honor of his long and lasting contributions to medical education and surgery, Dr Blades received the first annual Statesmen in Medicine award by the Airlie Foundation on September 17, 1969. The award was created to honor individuals making noteworthy contributions to the progress of medicine and subsequently came to bear his name. Among the luminaries at the awards ceremony were then Secretary of State Melvin Laird and Senator Edmund Muskie of Maine, who said of Dr Blades, "... he is a man who is an honor to the medical profession." A bronze bust of Blades, made by the Greek-born sculptor EvAngelos Frudakis, resides in his honor in the Federal Room at the Airlie House in Warrenton, Virginia. Among his many other awards is the Veterans Administration Commendation of 1963 and 1966 for his lifelong dedication to the development of the Veterans Administration Medical System, the University of Kansas Alumni Association Distinguished Service Award in 1953, and the Washington University Alumni Citation in 1961. In recognition of his long and important leadership of the Department of Surgery at GW, a portrait was commissioned in his honor in 1970 and hangs to this day in the department offices.

\section{THE FINAL DAYS}

Dr Blades died of a cerebrovascular accident on September 28,1977 , after returning home from a fishing trip in Florida. A memorial service was held in his honor at GW on November 26, 1977, attended by many friends, colleagues, and former trainees. Dr Edwin Beattie said, "I believe Brian and Ed Kent wrote one of the most important papers in modern day thoracic surgery because it started the era of safe thoracic surgery, namely, the individual ligation technique. I think Brian gets a great deal of credit for making pulmonary resection a safe procedure." Dr Murdoch Head reminisced, "Brian was a great surgeon, a pioneer, a teacher, but beyond that Brian Blades had style. 


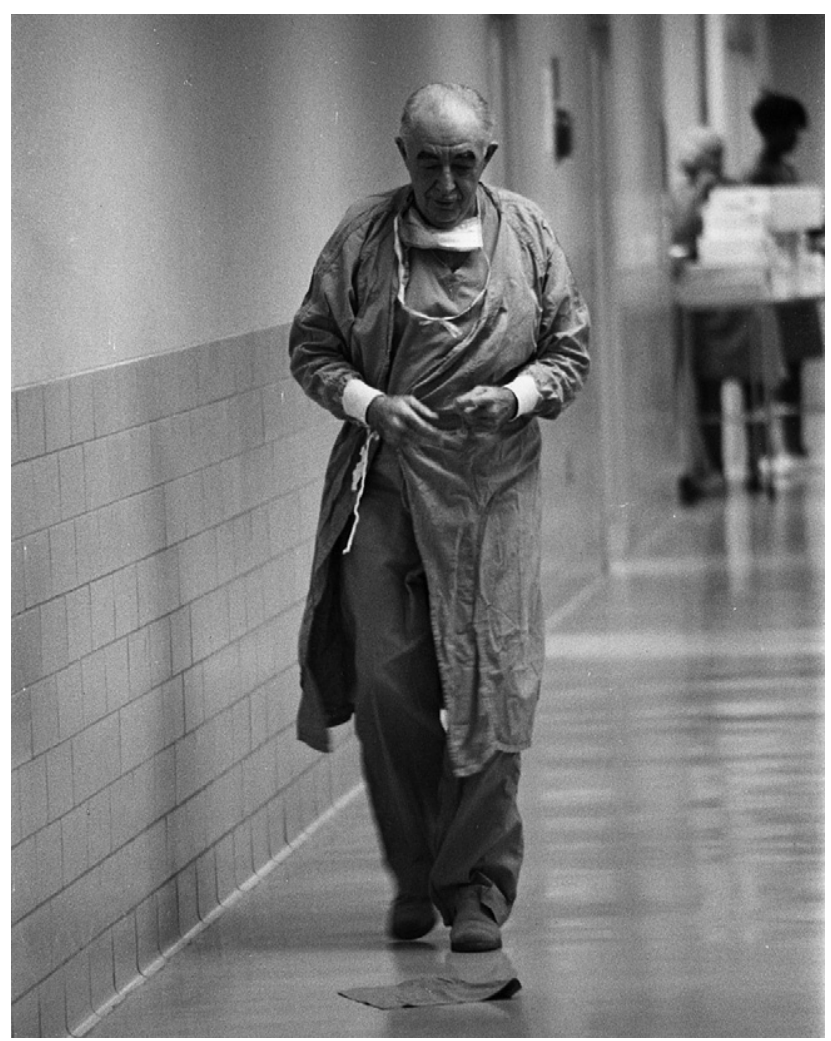

FIGURE 3. Dr Blades, the consummate clinician.

He was a man of great warmth and good humor." Dr Paul Shorb had the unique experience of attending medical school and training with some of the surgical giants at Hopkins in the 1950s and 1960s, as well as in thoracic surgery under Dr Blades, before joining him on faculty at GW. He recounted that Dr Blades was much "mellower than his Baltimore colleagues, but was still a commanding presence and when he entered a room you knew someone important had arrived." Perhaps the most fitting tribute to Dr Blades is contained in words written by Mark Twain, read at his eulogy, and presented by Dr Benjamin Aaron during the 19th Blades lecture at GW: "He was a true man, a brave man, an earnest man, a liberal man, a just man, a generous man, in all his ways and by all his instincts a noble man; he was a man of education and culture, a finished conversationalist, a ready, able and graceful speaker, a man of great brain, a broad and deep and weighty thinker. He was a great man—a very, very great man.” This was Dr Brian Brewer Blades (Figure 3).

I thank the many individuals who have contributed to the collection of information used in the article. Family members who have contributed include his daughter, Judy Hunt, his daughter-in-law, Judy Blades, and most importantly his grandson, Charles Hogue, of La Jolla, California, who provided me with a DVD of the largely biographical 19th Brian Blades Lecture presented by Dr Benjamin Aaron, from which some anecdotal material was taken. I thank $\mathrm{Mr}$ George Paul from the Himmelfarb Library at George Washington who provided copies of referenced and unreferenced publications about Dr Blades. Finally, I thank Drs Joseph Giordano and Dr Paul Shorb, who shared many years of personal recollections about Dr Blades.

\section{References}

1. Adkins PC. Brian Brewer Blades (1906-1977). J Thorac Cardiovasc Surg. 1978; 75:782-3.

2. Aaron B. 17th Annual Brian Blades Lecture. George Washington University School of Medicine; 1996 Oct 17.

3. Albert E. Statesman in Medicine Award Dinner. Airlie House, Warrenton (VA); 1969 Sept 17. 